\title{
Interaction between Apis mellifera L. and Baccharis dracunculifolia DC, that favours green propolis production in Minas Gerais
}

\author{
Bastos, EMAF. ${ }^{a *}$, Santana. RA. ${ }^{a}$, Calaça-Costa, AGF. ${ }^{b}$ and Thiago, PS. ${ }^{a}$ \\ ${ }^{a}$ Diretoria de Pesquisa e Desenvolvimento, Fundação Ezequiel Dias - FUNED, \\ Conde Pereira Carneiro, 80, Gameleira, CEP 30510-010, Belo Horizonte, MG, Brazil \\ 'Instituto de Ciências Exatas, Universidade Federal de Minas Gerais - UFMG, \\ Av. Antônio Carlos, 6627, Prédio do ICEX, Pampulha, CEP 31270-901, Belo Horizonte, MG, Brazil \\ *e-mail: embastos@funed.mg.gov.br \\ Received July 5, 2010 - Accepted September 20, 2010 - Distributed August 31, 2011
}

(With 5 figures)

\begin{abstract}
In Minas Gerais, green propolis is produced from the collection of resinous substance found in shoot apices of Baccharis dracunculifolia. The aim of this study was to evaluate the biological parameters associated with the interaction Apis mellifera $\mathrm{x}$ Baccharis dracunculifolia, to elucidate the supply of resin for green propolis production in Minas Gerais. We selected male and female individuals of two populations of Baccharis dracunculifolia located on São Judas Tadeu Farm - FSJT, in the municipality of Betim, MG and the Experimental Garden of the Ezequiel Dias Foundation - HORTO, located in an urban area in Belo Horizonte, MG. We made weekly observations, from June 2007 to June 2008, and evaluated in both populations: richness and abundance of insect visitors; resin collecting visits of Apis mellifera; presence of Baccharopelma dracunculifoliae galls; growth of individuals and phenological phases. Statistical analyses were made using R software. The rainy season showed the highest number of visitors. A. mellifera collected resin in shoot apices of Baccharis dracunculifolia from August to April, only in the FSJT population, where galls of B. dracunculifoliae were also present. Ovoposition of gall inductor on host plants occurs during the rainy season, when there is a peak of visitants and resin collecting visits of honeybees. This fact stimulates plant defense strategies against parasitoids and predators, which includes the production of several secondary metabolites, and ultimately reduces competition for food by inhibiting the attack of other phytophagous insects, not adapted to the chemical environment of plant tissues. Green propolis production in Minas Gerais is related to the abundant supply of resin by Baccharis dracunculifolia, when they are parasitised by $B$. dracunculifoliae galls. They induce plant production of defense exudates, which attract Apis mellifera bees to collect resin and consequently favour the production of green propolis.
\end{abstract}

Keywords: green propolis, galls, Baccharis dracunculifolia, Apis mellifera, Baccharopelma dracunculifoliae.

\section{Interação entre Apis mellifera L. e Baccharis dracunculifolia DC que favorecem a produção de própolis verde no estado de Minas Gerais}

\section{Resumo}

A própolis verde é produzida pelas abelhas Apis mellifera no estado de Minas Gerais, Brasil, a partir da coleta de substância resinosa dos ápices vegetativos de Baccharis dracunculifolia. O objetivo deste trabalho foi avaliar os parâmetros biológicos associados à interação Apis mellifera x Baccharis dracunculifolia, visando elucidar o fornecimento de resina da espécie para a produção de própolis verde em Minas Gerais. Foram selecionados indivíduos masculinos e femininos em duas populações de Baccharis dracunculifolia localizadas na Fazenda São Judas Tadeu - FSJT, município de Betim, MG, e no Horto Experimental da Fundação Ezequiel Dias - HORTO, em área urbana no município de Belo Horizonte, MG. Foram observados semanalmente, entre junho de 2007 e junho de 2008, a riqueza e abundância de insetos visitantes; visitação de Apis mellifera para coleta de resina; presença de galhas de Baccharopelma dracunculifoliae; crescimento dos indivíduos de Baccharis dracunculifolia e fenofases. Para análise estatística utilizou-se o software R. Em ambas as populações, a estação chuvosa foi a que apresentou maior número de visitantes. As abelhas Apis mellifera, coletaram resina nos ápices vegetativos de Baccharis dracunculifolia entre agosto e abril, e somente na população FSJT, onde ocorreram galhas de $B$. dracunculifoliae. Neste período a planta é ovopositada pelo indutor da galha que estimula a produção de diversos metabólitos secundários, como proteção ao ataque de parasitoides e predadores, e reduz a competição por alimento ao inibir o ataque de outros insetos fitófagos. A produção de própolis verde em Minas Gerais está relacionada à oferta abundante de resina pela planta Baccharis dracunculifolia, parasitadas por essas galhas. A atração das abelhas Apis mellifera para coleta de resina e produção de própolis verde se dá pela produção de exsudatos de defesa pela planta induzida pela presença da galha.

Palavras-chave: própolis verde, galhas, Baccharis dracunculifolia, Apis mellifera, Baccharopelma dracunculifoliae. 


\section{Introduction}

Baccharis is the largest genus of the subtribe Baccharidinae (Asteraceae) and is widely represented in South America with more than 500 native species (Barroso, 1976). Some species are typically invasors and occur mainly in denuded and empty areas, like margin of roads and railroads, plowed and not planted fields, pastureland, margins of ditches, fences and gaps (Palmer, 1987; Palmer and Bennett, 1988; Gagné and Boldt, 1989; Boldt and Robbins, 1987; Palmer, 1987). Species are dioecious, 0.5 to $4 \mathrm{~m}$ high, mostly evergreen shrubs and native from New World (Barroso, 1976). Baccharis dracunculifolia, popularly known as vassourinha, alecrim do campo or alecrim de vassoura, occurs from the southeast to the southern region of Brazil and extends into Argentina, Uruguay, Paraguay and Bolivia (Barroso, 1976). Plants occur in fields or open areas and constitute dense and dominant formations on uncultivated or degraded land (Araújo et al., 1995). In this species and others of the genus, blooming occurs after the rainy season (Boldt et al., 1988).

They have the highest diversity of galling insects in the tropics (Fernandes et al., 1994). Studies on insect-plant interactions consider that richness in herbivorous insect communities is influenced by the host plant characteristics, such as range of occurrence and structural complexity (Strong et al., 1984).

Quality and quantity of resources offered by the host plant also play an important role in herbivorous insect diversity (Price, 1992; Araújo et al., 1995; Marques et al., 2002; Espírito-Santo et al., 2004). According to Herms and Mattson (1992), plants adapted to stressful habitats (nutrient-poor) have better defenses against herbivore attack and when there are limited resources, allocation of these is selective on whether used for growing or for chemical defenses production. As nutrient deficiency limits growth, plants with small growth rates favour secondary compounds production (Herms and Mattson, 1992).

These compounds have many roles, and their presence is considered part of the plant defense strategy against herbivorous insects attack (Mani, 1964; Price et al., 1987, 1990). However, it is known that some herbivores use these secondary metabolites of plants to stop their own predators as proposed by Herms and Mattson (1992). Defense is not the only role of these substances, that can be also associated with pollinator attraction, ultraviolet light protection, structural support, temporary storage of nutrients and location of host plants (Price et al., 1987).

Several studies on insect fauna associated with Baccharis dracunculifolia sought knowledge of population control using potential species herbivores (Tilden, 1951; Kraft and Denno, 1982; Boldt and Robbins, 1987; Palmer, 1987). These herbivores frequently associated with Baccharis dracunculifolia in Brazil are galling insects of nine different and still unidentified species Cecidomyiidae (Diptera), and a species of Psyllidae, Baccharopelma dracunculifoliae (Hemiptera,Psyllidae) (Lara and Fernandes, 1994;
Fagundes et al., 2001; Arduin et al., 2005; Carneiro et al., 2009). Baccharopelma dracunculifoliae is restricted to the Neotropical Region (Burckhardt, 1987) and its biology and natural history are largely unknown. All hosts of B. dracunculifoliae belong to Baccharis genus (Burckhardt, 1987) and, in general, the psyllids are host specific of family, genus and species (Burckhardt et al., 2004).

Biological association of galling insects and plants do not imply plant benefits. On the other hand, galling insects have many advantages like shelter, nutrition, and spread. The adaptive value of this complex relationship - gall versus plant - has been widely discussed (Mani, 1964; Price et al., 1987; Isaias, 1998; Espírito Santo et al., 2004; Carneiro et al., 2009).

Galls are like drains, nutritionally supplied by direct vascular tissue connections of the host plant, where it assimilates direct flow, without any plant control (Hartley, 1998). Besides primary metabolites clearly related to inductor nutrition, galls are related to compounds originated from secondary metabolism, among which the most studied are phenolic derivatives. These substances are considered part of plant defense strategy to herbivorous insects attack (Mani, 1964; Price et al., 1987, 1990), and it seems that damaged tissues promote changes in metabolism phenolic derivatives, and also benefit insect gall. Increased production of these substances by the host plant could directly or indirectly protect galling insects from its parasitoids and predators, and moreover, inhibiting attacks of other phytophagous insects not adapted to this chemical environment of plant tissues, could reduce competition for food (Janzen, 1977; Cornell, 1983; Soares et al., 2000; Espírito-Santo et al., 2004).

Apis mellifera propolis has several functions in hives such as gap filling, reduction of entrance and exit spaces, mummification of dead insects for prevention of decay and putrefaction, covering hive inner walls, and inside broodcomb cells to prevent infestation from microorganisms (Ghisalberti, 1979).

The origin of green propolis produced by Apis mellifera in the state of Minas Gerais, Brazil, is a resinous substance collected in the shoot apices of Baccharis dracunculifolia (Oliveira et al., 1998; Bastos, 2000, 2001, 2002; Bastos et al., 2000, 2008). With a complex chemical composition, the main components are essential oils, phenols, polyphenols, flavanones, chalcones, and prenyilates derived from p-coumaric acid (Ghisalberti, 1979; Bonvehi et al., 1994; Marcucci, 1995, 1996; Marcucci et al., 2001; Matsuno, 1993; Greenaway et al., 1991; Walker and Crane, 1987; Bankova et al., 1996, 1998, 1999, 2000; Kumazawa et al., 2003).

The main goal of this study was to evaluate biological parameters associated to Apis mellifera $\mathrm{x}$ Baccharis dracunculifolia interaction, in order to discover how resin production by this plant species contributes to green propolis production in the state of Minas Gerais. 


\section{Material and Methods}

\subsection{Areas of study}

Two Baccharis dracunculifolia populations were used in this study:

Fazenda São Judas Tadeu-FSJT (UTM 584413 and 7802335), municipality of Betim, MG, presenting heterogeneous vegetation composed of native species, invasive exotic, ornamental and fruit trees. We studied 18 plants, 10 male and 8 female located in a successional area.

Experimental Garden of Ezequiel Dias FoundationHORTO (UTM 606202 e 7796212), in an urban area in Belo Horizonte, MG, where we studied 11 plants, 4 male and 7 female.

\subsection{Field observations}

Individuals of Baccharis dracunculifolia studied were identified by comparison with material from the herbarium of the Botany Department UFMG (BHCB 41 396). Individuals were randomly selected, numbered, sexed and marked with signs. Field observations comprised the period from June 2007 to May 2008 in FSJT population and from July 2007 to June 2008 in the HORTO population.

We evaluated the following parameters in both Baccharis dracunculifolia populations studied: 1) richness and abundance of visitor insects; 2) number of resin collecting visits of Apis mellifera; 3 ) presence of galls of Baccharopelma dracunculifoliae; 4) growth of Baccharis dracunculifolia individuals throughout the study period by measuring their stem diameter; and 5) Phenophases (flowering and vegetative state) of individuals.

Stem diameter, phenophases, and number of galls Baccharopelma dracunculifoliae were collected, recorded monthly. Galls estimation was performed according to the phases of development proposed by Arduim et al. (2005), and only the second phase was used in data analysis, because it was easier to recognise in the field (Figures 1 and 2).

Weekly observations were made between 10:30 AM and 3:00 PM, lasting 20 minutes on each individual (Ferracini, 1995), this, divided into two rounds of 10 minutes.

\subsection{Statistical analysis}

Field data, like number and types of visitors, especially Apis mellifera and the presence of galls Baccharopelma dracunculifoliae, may present a difference due to season (rainy or dry), environment (both studied populations) and gender of individuals (male and female).

To assess differences in the medians of the variables: number of visitors, number of $B$. dracunculifoliae galls phase two, stem diameter and resin collecting visits of A. mellifera, among dry and rainy seasons, and gender of individuals, we used the Mann-Whitney test. Correlation between variables was addressed by the Spearman coefficient.

Possible associations with $A$. mellifera visits (response variable) and explanatory variables: season, visitors, galls, gender and size of individuals, were verified using Chi-square test. Significance level was 5\%. Analyses were performed with the software R Development Core Team (2009).

\section{Results}

\subsection{Baccharis dracunculifolia visitors}

A total of 1645 visitors were observed in HORTO and 3875 visitors in FSJT. Of these, 1123 belong to the following orders: Coleoptera, Hemiptera, Homoptera, Orthoptera, Thysanoptera and Lepidoptera. In both populations, the order Hymenoptera was represented by $10-45 \%$ among the total number of visitors, the order Coleoptera 5-10\% and orders, Hemiptera, Homoptera, Lepidoptera, Mantodea, Odonata, Orthoptera, Neuroptera had a frequency $<1 \%$
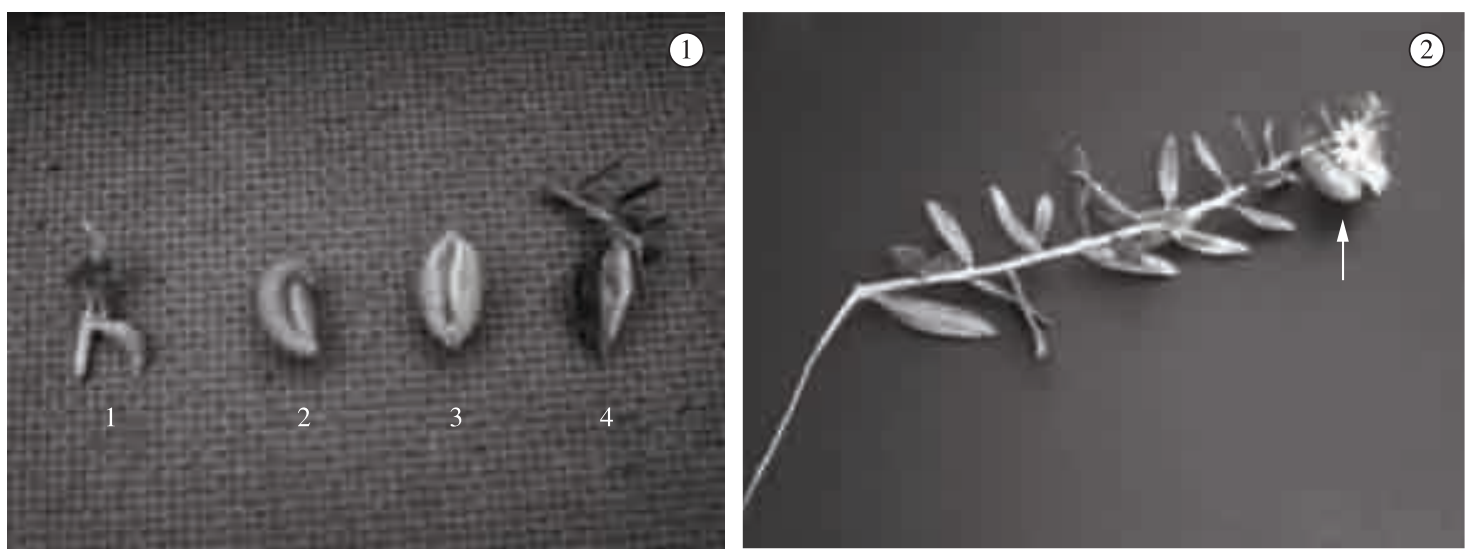

Figures 1-2. Baccharopelma dracunculifoliae gall. a) Gall development phases: Phase 1 - Swelling phase, leaf swelling in response to gall-inducing insect oviposition. Phase 2 - Folding phase, the leaf lamina folded upward alongside the midrib and the edges of the upper portion of the leaf approached each other, forming a longitudinal slit. Phase 3 - Dehiscence phase, Phase 4 - Senescence phase. b) Gall phase 2 among leaves (arrow) used in statistical analysis because of its easy recognition in the field. 
(Table 1). In both populations, the number of visitors observed was significantly different between dry and rainy seasons (Mann-Whitney test, $\mathrm{p}<0.05$ ).

Positive significant correlation of ants and other insect visitors was observed in both populations (FSJT: $r=0.287$, $\mathrm{n}=201, \mathrm{p}<0.05$; HORTO: $\mathrm{r}=0.311, \mathrm{n}=108, \mathrm{p}<0.05)$.

\subsection{Resin collecting visits of Apis mellifera}

For the FSJT population, resin collecting visits of A. mellifera (Figure 3) began in August and continued until April (Figure 4).Individuals from the HORTO population were not visited by Apis mellifera in order to collect resin.

In the FSJT population, there was a significant positive correlation of resin collecting visits of Apis mellifera with other visitors $(\mathrm{r}=0.177, \mathrm{n}=201, \mathrm{p}<0.05)$ and ants $(\mathrm{r}=0.141, \mathrm{n}=201, \mathrm{p}<0.05)$.

\subsection{Presence of Baccharopelma dracunculifoliae galls}

Baccharopelma dracunculifoliae galls were present only in the FSJT population and during the dry season (from April to July), had greater abundance of phase 2 galls (Figure 5).

The correlation coefficient of galls (phase 2) and resin collecting visits of Apis mellifera was not significant $(\mathrm{r}=-0.084, \mathrm{n}=155, \mathrm{p}=0.297)$, although showing an inverse relationship between them (Figures 4and 5).

\subsection{Growth of Baccharis dracunculifolia individuals}

Individual size showed significant positive correlation with other visitors in the HORTO population. In the FSJT population, individual size was positively correlated with

Table 1. Total number and percentage of visitors recorded in Baccharis dracunculifolia Individuals in Horto $(\mathrm{n}=11)$ and in FSJT population $(\mathrm{n}=18)$ during the study (from 2007 to 2008).

\begin{tabular}{lrr}
\hline \multicolumn{1}{c}{ Orders } & HORTO & FSJT \\
\hline Coleoptera & 202 & 279 \\
Formicidae & 484 & 1907 \\
Hemiptera & 59 & 197 \\
Homoptera & 86 & 174 \\
Hymenoptera & & \\
$\quad$ Apis mellifera & - & 147 \\
$\quad$ Bees and wasps* & 109 & 175 \\
Lepidoptera & 5 & 21 \\
Mantodea & 15 & 15 \\
Neuroptera & 5 & 4 \\
Odonata & 1 & 8 \\
Orthoptera & 4 & 86 \\
Thysanoptera & 3 & 7 \\
Indeterminate** & 71 & 128 \\
Total & 1645 & 3875 \\
\hline
\end{tabular}

*This group includes only other bees (except for A. mellifera) and wasps. **Visitors whose identification was not possible.
Baccharopelma dracunculifoliae galls and with resin collecting visits of Apis mellifera (Table 2).

\subsection{Phenological phases (flowering and vegetative state)}

The flowering period was from December to May and vegetative period from June to November, in both populations studied. During the flowering period, resin

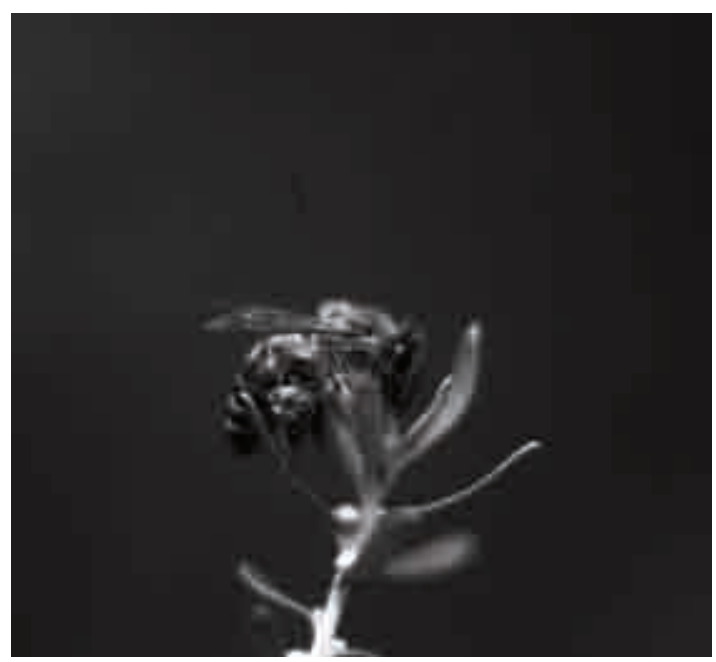

Figure 3. Apis mellifera bee collecting resin on shoot apices of Baccharis dracunculifolia oviposited by Baccharopelma dracunculifoliae (gall phase 1).

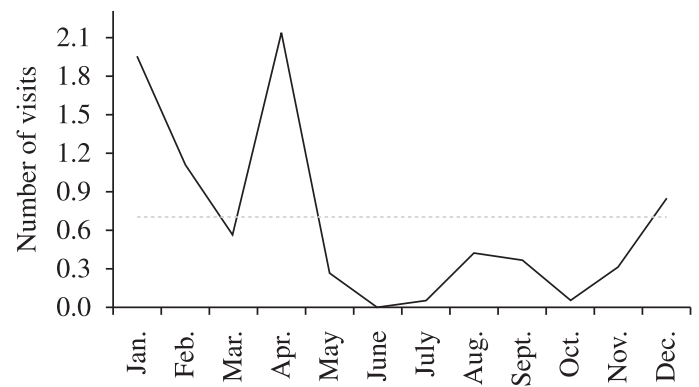

Figure 4. Number of resin collecting visits of Apis mellifera monthly recorded on $B$. dracunculifolia individuals, for the Fazenda São Judas Tadeu (FSJT) population. Horizontal line represents the mean.

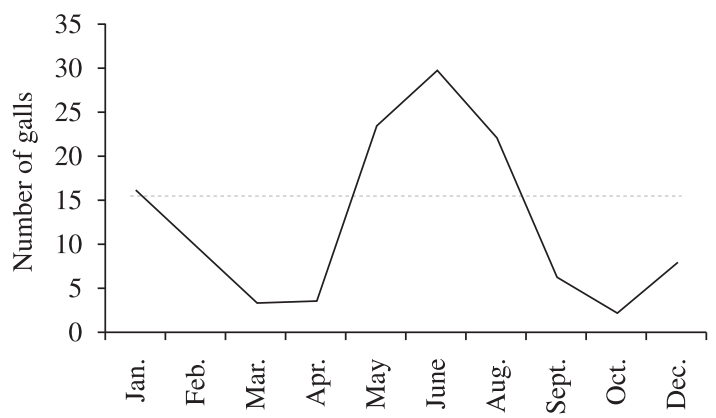

Figure 5. Number of Baccharopelma dracunculifoliae galls monthly recorded, for the Fazenda São Judas Tadeu (FSJT) population. Horizontal line represents the mean. 
Table 2. Spearman's correlation coefficient of individual size and biological parameters in both studied populations, FSJT $(\mathrm{n}=18)$ and HORTO $(\mathrm{n}=11)$.

\begin{tabular}{lccc}
\hline & Visitors (HORTO) & B. dracunculifoliae Galls (FSJT) & A. mellifera visits (FSJT) \\
\hline $\mathrm{R}$ & 0.311 & -0.215 & 0.219 \\
$\mathrm{p}$-value & 0.001 & 0.009 & 0.007 \\
\hline
\end{tabular}

Table 3. Results of Mann-Whitney test of biological parameters: herbivores, ants, size of individuals, galls of B. dracunculifoliae and resin collecting visits of A. mellifera, among gender (male and female).

\begin{tabular}{lcc}
\hline \multirow{2}{*}{ Parameters } & \multicolumn{2}{c}{ p-value } \\
\cline { 2 - 3 } & FSJT & Horto FUNED \\
\hline Others visitors & 0.462 & 0.595 \\
Ants & 0.199 & 0.002 \\
Size & 0.000 & 0.351 \\
Galls & 0.868 & - \\
Apis mellifera & 0.569 & - \\
\hline
\end{tabular}

All null hypothesis were that male and female medians were equal and alternative hypothesis were that male and female medians were different for each parameter. *Resin collecting visits of A. mellifera.

collecting visits of Apis mellifera to vegetative apices occurred in the FSJT population.

There was no significant difference of biological parameters of (Baccharopelma dracunculifoliae galls, resin collecting visits of Apis mellifera, and number of others visitors) among male and female individuals (Table 3 ).

Only size showed difference between gender in FSJT population and number of ants in the HORTO population (Table 3).

\section{Discussion}

The highest number of visitors was recorded in the rainy season in both populations, in agreement with Araújo et al. (1995), who reported that the greater abundance of herbivores on B. dracunculifolia during the rainy season and reproductive state is related with a major resource offered.

After this period, most of the leaves fall, giving the shrub a dry aspect. The sprouting of new leaves comes with the rain, and consequently, the abundance of herbivorous insects.

Resin collecting visits by honeybees (Figure 4) occurred from August to April, and in December, January, February and April there was the highest frequency. The rainy season also showed higher visitation of ants and other insects.

The genus Baccharis produces exudates that attract a variety of flying insects (Boldt et al., 1988; Boldt and Robbins, 1990) and these substances occur naturally in the plant or its production is stimulated by insect injured leaves, stems or other plant parts.

Green propolis harvest in the state of Minas Gerais, starts in August and lasts until April (Lima, 2006), and the results show that during this same period, honeybees collect resin on B. dracunculifolia individuals. Previous studies on seasonal production of essential oils in populations of
B. dracunculifolia showed higher rates of production from February to April and the lowest during May, June and July (Souza, 2007), in agreement with results reported here.

Galls caused by the psyllid Baccharopelma dracunculifoliae were present only in the population of FSJT, where resin collecting visits of $A$. mellifera occurred. The second phase of the gall, which was used in this work to count for them, was higher from April to July, during the dry season (Figure 5).

Therefore, it is during the rainy season that the oviposition of gall inductor on host plants occurs, with the peak of visitants and resin collecting visits of honeybees. This fact stimulates plant defense strategies against parasitoids and predators, which includes the production of several secondary metabolites, and ultimately reduces competition for food by inhibiting the attack of other phytophagous insects, not adapted to the chemical environment of plant tissues (Janzen, 1977; Cornell, 1983; Isaias, 1998; Soares et al., 2000).

The most commonly studied compound of plant secondary metabolism are phenolic derivates. The presence of these substances is considered part of the plant defense strategy against attack by herbivorous insects (Mani, 1964; Price et al., 1987; Price et al., 1990).

Honeybees take advantage of the interaction B. dracunculifolia x Baccharopelma dracunculifoliae, by collecting this resinous substance filled with phenolic compounds, which gives green propolis its biological activities already recognised in literature (Bankova et al., 1998, 1999, 2000; Tazawa et al., 1998; Marcucci, 1995; 1996; Marcucci et al., 2001; Park et al., 1997, 2002; Castaldo and Capasso, 2002; Sawaya et al., 2004).

Contrarily the, HORTO population did not develop these galls. Probably this is due to its isolation within an urban area, and according to previous studies (Araújo et al., 
1995; Fernandes et al., 1994; Burckhardt et al., 2004; Julião et al., 2005), the psyllid has little ability to fly and a small time interval is required between the colonisation of a particular site by the host plant and the arrival of this gall inductor. Additionally, the degree of the host plant population isolation also represents another important factor for the arrival of this insect.

In this population, the absence of resin collecting visits of A. mellifera as well as B. dracunculifoliae galls, confirms the relationship between presence of the psyllid and the production of exudates by host plants as a defense strategy.

Individual size showed positive significant correlation with other visitors, with the presence of Baccharopelma dracunculifoliae galls and with resin collecting visits of A. mellifera in FSJT, which are all in agreement with the literature (Espírito-Santo and Fernandes, 1998; Collevatti and Sperber, 1997).

During blooming period, from December to May, there was no resin collecting visits of $A$. mellifera, and these are not significantly different among male and female plants. This shows that resin production by Baccharis dracunculifolia plants is not related to its phenological aspects, but with the presence of metabolic inductors like galling insects.

\section{Conclusion}

During the rainy season, Baccharis dracunculifolia populations secretes a number of exsudates that attract ants, others insects and Apis mellifera bees for resin collecting visits.

These resin collecting visits on vegetative apices occur on Baccharis dracunculifolia individuals that are oviposited by Baccharopelma dracunculifoliae galls, during the rainy season. Bees collect independently of individuals gender (male or female) and its phenological state (flowering or vegetative), and the period of high resin collecting visits coincides with the harvest of green propolis in Minas Gerais.

Acknowledgements - The authors are grateful to the Fundação de Amparo à Pesquisa do Estado de Minas Gerais for financial support.

\section{References}

ARAÚJO, AM., FERNANDES, GW. and BEDÊ, LC., 1995. Influência do sexo e fenologia de Baccharis dracunculifolia DC (Asteraceae) sobre insetos herbívoros. Revista Brasileira de Entomologia, vol. 39, no. 2, p. 347-353.

ARDUIN, M., FERNANDES, GW. and KRAUS, JE., 2005. Morphogenesis of galls induced by Baccharopelma dracunculifoliae (Hemiptera: Psyllidae) on Baccharis dracunculifolia (Asteraceae) leaves. Brazilian Journal of Biology, vol. 65, no. 4, p. 559-571. http://dx.doi.org/10.1590/S1519-69842005000400002

BANKOVA, V., BOUDOUROVA-KRASTEVA, G., POPOV, S., SFORCIN, JM. and FUNARI, SRC., 1998. Seasonal variations of the chemical composition of Brazilian propolis. Apidologie, vol. 29, p. 361-367. http://dx.doi.org/10.1051/apido:19980406
BANKOVA, V., BOUDOUROVA-KRASTEVA, G., SFORCIN, JM., FRETE, X., KUJUMGIEV, A., MAIMONI-RODELLA, R. and POPOV, S., 1999. Phytochemical evidence for the plant origin of Brazilian propolis from São Paulo State. Zeitschrift für Naturforschung $C$, vol. 54c, p. 401-405.

BANKOVA, V., CASTRO, SL. and MARCUCCI, MC., 2000. Propolis: Recent advances in chemistry and plant origin. Apidologie, vol. 31, p. 3-15. http://dx.doi.org/10.1051/apido:2000102

BANKOVA, V., MARCUCCI, MC., SIMOVA, S., NIKOLOVA, N., KUJUMGIEV, A. and POPOV, S., 1996. Antibacterial diterpenic acids from Brazilian propolis. Zeitschrift für Naturforschung C, vol. 51c, p. 277-280.

BARROSO, G., 1976. Compositae: Subtribo Baccharidinae Hoffmann Estudo das espécies ocorrentes no Brasil. Rodriguésia, vol. 40 , p. 1-273.

BASTOS, EMAF., 2000. Origem botânica, propriedades físicoquímicas e atividade antimicrobiana da própolis verde, produzida em Minas Gerais. In Anais do IV Encontro sobre Abelhas, 2000. Ribeirão Preto.

-, 2001. Origem botânica e indicadores de qualidade da própolis verde produzida no Estado de Minas Gerais. Ribeirão Preto: Universidade de São Paulo. 137 p. tese de Doutorado em Entomologia.

-, 2002. Abelhas: Pesquisa revela o potencial da própolis verde, característica de Minas Gerais. Minas Faz Ciência, no. 9, p. 14-17.

BASTOS, EMAF., OLIVEIRA, VC. and SOARES, AEE., 2000. Microscopic characterization of the green propolis, produced in Minas Gerais State, Brazil. Honeybee Science, vol. 21, no. 4, p. $179-180$.

BASTOS, EMAF., SIMONE, M., JORGE, DM., SOARES, AEE. and SPIVAK, M., 2008. In vitro study of the antimicrobial activity of Brazilian propolis against Paenibacillus larvae. Journal of Invertebrate Pathology, vol. 97, p. 273-281. PMid:18054037. http://dx.doi.org/10.1016/j.jip.2007.10.007

BOLDT, PE. and ROBBINS, TO., 1987. Phytophagous and pollinating insect fauna of Baccharis neglecta (Compositae) in Texas. Environmental Entomology, vol. 16, p. 887-895.

-, 1990. Phytophagous and flower-visiting fauna of Baccharis salicifolia (Asteraceae) in the southwestern United States and northern Mexico. Environmental Entomology, vol. 19, no. 3, p. $515-523$

BOLDT, PE., WOODS, W. and ROBBINS, TO., 1988. Phytophagous insect fauna of Baccharis sarathroides (Asteraceae) in Arizona and New Mexico. Proceedings of the Entomological Society of Washington, vol. 90, p. 207-215.

BONVEHI, JS., COLL, FV. and JORDÁ, RE., 1994. The composition, active components and bacteriostatic activity of propolis in dietetics. Journal of American Oil Chemists Society, vol. 71, no. 5, p. 529-532. http://dx.doi.org/10.1007/BF02540666

BURCKHARDT, D., 1987. Jumping plant lice (Homoptera: Psylloidea) of the temperate neotropical region. Part 1: Psyllidae (subfamilies Aphalarinae, Rhinocolinae and Aphalaroidinae). Zoological Journal of Linnaean Society, vol. 89, p. 299-392. http://dx.doi.org/10.1111/j.1096-3642.1987.tb01568.x

BURCKHARDT, D., ESPÍRITO-SANTO, MM., FERNANDES, GW. and MALENOVSKÝ, I., 2004. Gall-inducing jumping plant-lice of neotropical genus Baccharopelma (Hemiptera, Psylloidea) associated with Baccharis (Asteraceae). Journal of Natural History, vol. 38, p. 2051-2071. http://dx.doi.org/10.1080/0022293032000140903 
CARNEIRO, MAA., BRANCO, CSA., BRAGA, CED., ALMADA, ED., COSTA, MBM., MAIA, VC. AND FERNANDES, GW., 2009. Are gall midge species (Diptera, Cecidomyiidae) host-plant specialists? Revista Brasileira de Entomologia, vol. 53, p. 365-378.

CASTALDO, S. and CAPASSO, F., 2002. Propolis, an old remedy used in modern medicine. Fitoterapia, vol. 73 (suppl. 1), p. S1-S6. http://dx.doi.org/10.1016/S0367-326X(02)00185-5

COLLEVATTI, RG. and SPERBER, CF., 1997. The gall maker Neoplema baccharidis Burck. (Homoptera: Psyllidade) on Baccharis dracunculifolia DC. (Asteraceae): individual, local, and regional patterns. Anais da Sociedade Entomológica do Brasil, vol. 26, p. 45-53.

CORNELL, HV., 1983. The secondary chemistry and complex morphology of galls formed by Cynipinae (Hymenoptera): why and how? American Midland Naturalist, vol. 110, p. 225-234. http://dx.doi.org/10.2307/2425263

ESPÍRITO-SANTO, MM. and FERNANDES, GW., 1998. Abundance of Neopelma baccharidis (Homoptera: Pysillidae) galls on the dioecious shrub Baccharis dracunculifolia (Asteraceae). Environmental Entomology, vol. 27, p. 870-876. http://dx.doi. org/10.1016/j.baae.2004.04.010

ESPÍRITO-SANTO, MM., FARIA, ML. and FERNANDES, GW. 2004. Parasitoid attack and its consequence of the galling psyllid Baccharopelma dracunculifoliae. Basic and Applied Ecology, vol. 5, p. 475-484.

FAGUNDES, M., FARIA, ML. and FERNANDES, GW., 2001. Efeitos da distribuição de Baccharis dracunculifolia (Asteraceae) na abundância e no parasitismo de galhas de Neopelma baccharidis (Homoptera: Psyllidae). Unimontes Cientifica, vol. 1, no. 1, p. 97-103.

FERNANDES, GW., LARA, ACF. and PRICE, PW., 1994. The geography of galling insects and the mechanisms resulting in patterns. In PRICE, PW., MATTSON, WJ. and BARANCHIKOV, Y. (Eds.). The ecology and evolution of gall-forming insects. St. Paul: Forest service, U.S. Department Agriculture. p. 42-48.

FERRACINI, VL., PARAIBA, LC., LEITÃO-FILHO, HF., SILVA, AGD., NASCIMENTO, LR. and MARSAIOLI, AJ., 1995. Essential oils of seven Brazilian Baccharis species. The Journal of Essential Oil Research, vol. 7, p. 355-367.

GAGNÉ, RJ. and BOLDT, PE., 1989. A new species of Neolasioptera (Diptera: Cecidomyiidae) from Baccharis (Asteraceae) in southern United States in Dominican Republic. Proceedings of the Entomological Society of Washington, vol. 91, p. 169-174.

GHISALBERTI, EL., 1979. Propolis: a review. Bee World, vol. 60 , no. 2 , p. 59-84.

GREENAWAY, W., MAY, J., SCAYSBROOK, T., and WHATLEY, FR., 1991. Identification by gas chromathography-mass spectrometry of 150 compounds in propolis. Zeitschrift für Naturforschung C, vol. 46, p. 111-121.

HARTLEY, SE., 1998. The chemical composition of plant galls: are level of nutrients and secondary compounds controlled by the gall-former? Oecologia, vol. 113, p. 492-501. http://dx.doi. org/10.1007/s004420050401

HERMS, DA. and MATTSON, WJ., 1992. The dilemma of plants: To grow or defend. The Quarterly Review of Biology, vol. 67, p. 283-335. http://dx.doi.org/10.1086/417659

ISAIAS, RMS. ,1998. Galhas entomógenas em Machaerium (Leguminosae, Papilionoideae): anatomia e histoquímica. São
Paulo: Universidade São Paulo. Tese de Doutorado em Ciências Biológicas (Botânica).

JANZEN, DH., 1977. Why fruits rot, seeds mold and meat spoils. American Naturalist, vol. 111, p. 691-713. http://dx.doi. org/10.1086/283200

JULIÃO, GR., FERNANDES, GW., NEGREIROS, D., BEDÊ, L. and ARAÚJO, RC., 2005. Insetos galhadores associados a duas espécies de plantas invasoras de áreas urbanas e peri-urbanas. Revista Brasileira de Entomologia, vol. 49, no. 1, p. 97-106.

KRAFT, SK. and DENNO, RF., 1982. Feeding responses of adapted insects to the defensive properties of Baccharis halimifolia L. (Compositae). Oecologia, vol. 52, p. 156-163.

KUMAZAWA, S., YONEDA, M., SHIBATA, I., KANAEDA, J., HAMASAKA, T. and NAKAYAMA, T., 2003. Direct evidence for the plant origin of Brazilian propolis by the observation of honeybee behavior and phytochemical analysis. Chemical \& Pharmaceutical Bulletin, vol. 51, no. 6, p. 740-742. http://dx.doi. org/10.1248/cpb.51.740

LARA, ACF. and FERNANDES, GW., 1994. Distribuição de galhas de Neopelma baccharidis (Homoptera: Psyllidae) em Baccharis dracunculifolia (Asteraceae). Revista Brasileira de Biologia $=$ Brazilian Journal of Biology, vol. 54, no. 4, p. 661-668.

LIMA, MG., 2006. A produção de própolis no Brasil. São João da Boa Vista: São João Editora e Gráfica. 120 p.

MANI, MS., 1964. Ecology of plant galls. The Hague, Netherlands: Dr. W. Junk. 604 p.

MARCUCCI, MC., 1995. Propolis: chemical composition, biological properties and therapeutic activity. Apidologie, vol. 26, p. 83-99. http://dx.doi.org/10.1051/apido:19950202

MARCUCCI, MC., 1996. Propriedades biológicas e farmacêuticas dos constituintes da própolis. Química Nova, vol. 19, no. 5, p. $529-536$.

MARCUCCI, MC., FERRERES, F., GARCÍA-VIGUERA, C., BANKOVA, VS., DE CASTRO, SL., DANTAS, AP., VALENTE, PHM. and PAULINO, N., 2001. Phenolic compounds from Brazilian propolis with pharmacological activities. Journal of Ethnopharmacology, vol. 74, p. 105-112. http://dx.doi.org/10.1016/ S0378-8741(00)00326-3

MARQUES, ESA., FERNANDES, GW., RIBEIRO-MENDES, HNT. and SILVA, IM., 2002. Influence of host-plant sex and habitat on survivorship of insect galls within the geographical range of the host-plant. Tropical Zoology, vol. 15, no. 1, p. 5-15.

MATSUNO, T., 1993. Isolation and characterization of the tumoricidal substance from Brazilian propolis. Honeybee Science, vol. 13 , p. $49-54$

OLIVEIRA, VC. and BASTOS, EMAF., 1998. Aspectos morfoanatômicos da folha de Baccharis dracunculifolia DC (Asteraceae) visando a identificação da origem botânica da própolis. Acta Botanica Brasilica, vol. 12, no. 3, p. 431-439.

PALMER, WA., 1987. The phytophagous insect fauna associated with Baccharis halimifolia L. and B. neglecta Britton in Texas, Louisiana, and northern Mexico. Proceedings of the Entomological Society of Washington, vol. 89, p. 185-199.

PALMER, WA. and BENNETT, FD., 1988. The phytophagous insect fauna associated with Baccharis halimifolia L. in the eastern United States. Proceedings of the Entomological Society of Washington, vol. 90, p. 216-228. 
PARK, YK., ALENCAR, SM. and AGUIAR, CL., 2002. Botanical origin and chemical composition of Brazilian propolis. Journal of Agricultural and Food Chemistry, vol. 50, p. 2502-2506. PMid:11958612. http://dx.doi.org/10.1021/jf011432b

PARK, YK., KOO, MH., IKEGAKI, M. and CONTADO, JL., 1997. Comparison of the flavonoid aglycone contents of Apis mellifera propolis from various regions of Brazil. Brazilian Archives of Biology and Technology, vol. 40, no. 1, p. 97-106.

PRICE, PW., 1992. The resource-based organization of comunities. Biotropica, vol. 24, p. 273-82.

PRICE, PW., COBB, N., CRAIG, TP., FERNANDES, GW., ITAMI, JK., MOPPER, S. and PRESZLER, RW., 1990. Insect herbivore population dynamics on trees and shrubs: new approaches relevant to latent and eruptive species. In BERNAYS, EA. (Ed.), Insectplant interations. Florida: Boca Raton, CRS Press. p. 1-38. vol. 2.

PRICE, PW., ROININEN, H. and TAHVANAINEN, J., 1987. Plant age and attack by bud galler, Euura mucronata. Oecologia, vol. 73, p. 334-337.

R Development Core Team, 2009. R: A language and environment for statistical computing. Vienna, Austria: R Foundation for Statistical Computing.

SAWAYA, ACHF., SOUZA, KS. AND MARCUCCI, MC., CUNHA, IBS. and SHIMIZU, MT., 2004. Analysis of the composition of Brazilian propolis extracts by chromatography and evaluation of their in vitro activity against Gram-positive bacteria. Brazilian Journal of Microbiology, vol. 35, p. 104-109.

SOARES, GLG., ISAIAS, RMS., GONÇALVES, SJMR. and CHRISTIANO, JCS., 2000. Alterações químicas induzidas por coccídeos galhadores (Coccoidea, Brachyscelidae) em folhas de Rollinia laurifolia Schdtl. (Annonaceae). Revista Brasileira de Zoociências, vol. 2, p. 103-116.

SOUZA, JPR., 2007. Influencia da sazonalidade no perfil químico dos óleos essenciais e das substâncias fixas de Baccharis dracunculifolia cultivada, utilizando-se cromatografia em fases gasosa e líquida. Ribeirão Preto: Faculdade de Ciências Farmacêuticas de Ribeirão Preto, Universidade São Paulo.

Dissertação de Mestrado em Produtos Naturais e Sintéticos.

STRONG, DR., LAWTON, JH. and SOUTHWOOD, TRE., 1984. Insects on plants: community patterns and mechanisms. Oxford: Blackwell Scientific Publications. 245 p.

TAZAWA, S., WARASHINA, T. NORO, T. and MIYASE, T., 1998. Studies on the constituents of Brazilian propolis. Chemical \& Pharmaceutical Bulletin, vol. 46, p. 1477-1479.

TILDEN, JW., 1951. The insects associates of Baccharis pilularis De Candolle. Microentomology, vol. 16, p. 149-188.

WALKER, P. and CRANE, E., 1987. Constituents of propolis. Apidologie, vol. 18, p. 327-334. http://dx.doi.org/10.1051/ apido: 19870404 